\title{
Dora I: from submarine pen to cultural bunker
}

\author{
S. Carstens \\ Social Sciences Division, Faculty of Teacher and Interpreter Education, \\ Sør-Trøndelag University College, Norway
}

\begin{abstract}
Dora I is originally a German U-boat bunker constructed during World War II in the harbour of Trondheim, Norway. In 1961 Dora I was sold to private investors who put it to use as a warehouse. During the 1990s it became evident that postwar construction and adaptation had contributed to establishing a unique microclimate within Dora I. Without any use of artificial ventilation or heating systems, the temperature inside the building changes slowly from summer to winter and varies less than $10^{\circ} \mathrm{C}$ over the year. The relative humidity stays pretty much stable the year around. This fact, combined with the lack of any natural light inside the massive building, makes it very well suited for long time storage of any type of organic material collected by museums, archives and libraries. In 2006, a new archival centre opened next to Dora I, collocating four in principle independent archival institutions. This archive centre uses the former submarine pens as depositories, storing currently approximately 130000 shelf meters of documents. In addition, a number of regional museums and art collections have established themselves with depositories in Dora I. At present Dora I is slowly turning into a multicultural regional centre hosting concerts, theatre plays and art exhibitions.

Keywords: World War II, archive, climate measurement, archive, museum, library storage, environment.
\end{abstract}

\section{Introduction}

On April 9, 1940, Norway was invaded by Nazi Germany. By the evening that day, the German forces had taken control of Oslo, the Norwegian capital, and the main coastal cities, Trondheim included. On April 25, Gauleiter in Essen and Oberpräsident der Rheinprovinz, Joseph Terboven (1898-1945), was appointed Reichskommissar for the Norwegian occupied areas [1]. 
His task was to attend to the German interests in Norway and to be the supreme government authority in all civilian cases [2]. Terboven was directly subordinate to Hitler only. In quick succession of Terbovens appointment to Reichkommisar, the Allied forces fighting alongside the Norwegian army was pulled out of the southern part of Norway and on May 5, the fighting in the southern part of Norway ceased as the last army group gave up resistance at Hegra fortress just north of Trondheim.

Having conquered Narvik from the Germans on May 28, the Allied forces three days later had to pull out of Norway in order to be transported to the continent, where they were most needed as Germany was about to conquer France. The Norwegian King and his government then left the country onboard the British County-class heavy cruiser HMS Devonshire sailing from Tromsø on June 7. Thus, the German occupation was a fact. On June 10, Lieutenant Colonel Ragnvald Rocher Nielsen (1891-1979) signed a controversial Norwegian capitulation statement in Trondheim; controversial as the Norwegian government kept on fighting the Germans from their exile in Great Britain.

\section{The reason why and the plans}

There of course were a variety of reasons why Nazi Germany decided to occupy Norway in 1940. One was to get ahead of any possible British occupation, another and perhaps even just as important, one can argue, was the desire to acquire naval bases on the Norwegian coast. During World War I, the British Navy effectively had managed to keep the German navy trapped in the Baltic Sea. This fact led German naval strategists to argue in favour of establishing forward German bases on the coast of Norway. Especially the Trondheim fjord area stood out positively in this context. The Trondheim fjord has only one narrow approach is very deep and has next to no islands. From central Norway, large German vessels could easily go on swift missions to interfere with, or preferably destroy, merchant and naval allied vessels sailing in the North Atlantic (Sivertsen [3]).

What future potential the Trondheim fjord area had as a naval base, viewed with German eyes, is emphasized by the fact that Adolf Hitler (1889-1945) personally suggested the need for a speedy construction of a great new naval port south of Trondheim to be named Neu-Drontheim (Brovold [4]). General Building Inspector Albert Speer (1905-1981), later armaments minister, was heavily involved in the Neu-Drontheim plans. In his autobiography, "Erinnerungen" Speer describes the plan for a large city in central Norway. With 300000 inhabitants the naval base by Trondheim would in Hitler's own words be demoting Singapore to "child's game" (Kinderspiel) in comparison.

Awaiting the construction of Neu-Drontheim, the Germans immediately needed to maintain and repair ships and submarines stationed in the Trondheim fjord. During the spring of 1940, the German Kriegsmarine therefore established the shipyard organisation Kriegsmarinewerft Drontheim (Sivertsen [5]). In the spring of 1941, this organisation, led by director Eduard Eichel (1880-1956), decided to use Nyhavna, a landfill made next to the estuary of the river floating 
through the city centre of Trondheim, as the site for the construction of Ubootstützpunkt Dora. The idea was to erect two submarine shelters, Dora I and Dora II, here (Sivertsen [6]). The effort to implement this was left to Organization Todt (OT), Einsatzgruppe Wiking and Sager \& Wörner, a construction company from Munich (Sivertsen [7]).

\section{The construction of Dora I}

The Dora Submarine shelters became the northernmost of the German submarine bunkers established during World War II. In 1940, Trondheim was a sleepy town on the outskirts of Europe with railway connection to Oslo and through Sweden to the continent. In addition, it had a well-developed harbour. Despite these obvious assets, the constructions of Dora I alone, during the on-going global war, proved to be a monstrous task. The fact that the construction of Dora II never was completed demonstrates this.

According to the German construction manager the task was just as resource demanding as working in the underdeveloped part of the world (Neitzel [8]). Norwegian cement did not have the quality needed, and the reinforcing bars available from Norwegian producers were not available in the quantity or quality needed. All the building materials needed therefore had to be imported from overseas. To build Dora I alone, it was necessary to be able to produce 207369 cubic meters of concrete. To achieve that 5 million 50 kilo sacks of cement had to be brought in from the continent. As the war evolved, the Germans faced increasing difficulties transporting the necessary building materials to Trondheim.

Freshwater-washed sand and rubble was the only material found in usable and locally available quantities. In order to be able to transport this and additional building materials into and around on the building site, it proved necessary to import large amounts of railway equipment, including locomotives and entire sets of different carriages from Germany where this kind of equipment was desperately needed. In addition, 300 lorries were needed and had to be shipped from Germany together with a countless number of barges and vessels to transport the necessary amounts of sand and rubble into the building site. At the most, the project's demand for manpower was reckoned to be between 6000 and 7000 men, but seldom more than 2000 were available as the extensive German activity in Norway soon created a tight labour market (Sivertsen [9]).

During the construction of Dora I, OT met massive challenges stabilizing the ground at the building site. It appeared to consist of a very loose mix of silt and clay. Nowhere was it possible to anchor the building to firm rock so the construction had to be able to sustain itself "floating" on the unstable seabed. In spite of the geological challenges, Dora I was ready for use by the summer of 1943. On July 20, OT formally handed over the submarine pen Dora I to the "Kriegsmarine" as the home base of the $13^{\text {th }}$ German submarine feet (Sivertsen [10]).

The dimensions of Dora I are $153 \times 105 \mathrm{~m}(167 \times 115 \mathrm{yd})$ at its base, covering about 16000 square metres. It was fitted with a steel reinforced 
concrete roof $3,7 \mathrm{~m}$ (12ft.) thick. The steel reinforced concrete walls are $3 \mathrm{~m}$ (9 $\mathrm{ft} .10 \mathrm{in})$ thick. The building rises some $22 \mathrm{~m}$ above the ground and is slightly larger beneath. The whole construction has an estimated weight of some 660000 tons.

The building of the Dora submarine bunkers was initiated in order to establish a protective shelter where one could undertake maintenance and repair tasks on German submarines stationed in Norway. The pens were under construction from 1941 to March 1945, using mostly highly skilled labour from all over the occupied Europe as well as a small number of slave labourers.

\section{Post war use}

In May 1945, Marinewerft Drondtheim was surrendered to allied and Norwegian forces. During the summer, the new Norwegian submarine force, set up in Britain during the war, took up quarters in Dora I. Already in 1954, however, the Norwegian navy decided to move the submarine base to Bergen and the German bunker there, Bruno. This represented the end of the use of Dora I for its original purpose.

In 1961 Dora I was offered up for sale on the open market and an Oslo-based company later named Dora Ltd. acquired the bunker. Their main business idea was to convert the old submarine bunker into a giant combined storage and workshop building. To achieve this they had to carry out extensive reconstruction works adding new inner floors. By doing this they converted the submarine shelter into a two floor building consisting of large halls approximately 6 meters high and up to 100 meters long. In addition Dora I was fitted with a new roof during the 1970s. Dora I, in reality, consists of several large concrete building elements that are able to move independently of each other. This means that though the building there runs several sets of expansion joints. These joints, despite being relatively narrow, make it possible for water seep in. The "new" modern light steel beam roof was erected standing upon the original bomb protective 3.7 meter heavy steel enforced roof. With this alteration, Dora I came to represent slightly less than 50000 square metres available for commercial letting.

A number of smaller and larger tenants have as the years passed been located in the building. It was one of these, a local paper wholesaler, who first discovered the quality climate that had evolved in Dora I as a result of reconstruction work conducted.

\section{The regional state archive of Trondheim}

The regional State Archives in Trondheim is the oldest of all the regional state archives in Scandinavia, established in 1850 (Lovlien [11]). Initially the institution was established at Kristiansten Fortress from 1684 just east of the city centre. In 1865, the institution could move to a specially designed archive building in the centre of Trondheim. It soon became evident that even this building was too small to hold the amount of archives that was being transferred 
from public administration to the institution. In 1927 yet another new archival building was ready for the institution. This building was by the beginning of the 1970 s completely filled with documents and in reality technically totally outdated. The institution had during the 1970s and 80s made several attempts to persuade the National Archivist that a new bulling vas vital in order to make the institution fulfil its obligations. The lack of sufficient space in fact came to inhibit professional activity, and in the early 90s, the regional archive more or less was forced to find a premise that could function as long-time temporary depositories. In the search for such premises, the archive learned about the paper wholesaler's experiences with storing paper in Dora I. The owner of the Dora I was contacted and meetings undertaken, the outcome being that the regional archive rented part of one of the Dora I hall's 500 square meter. By the use of simple fixed steel racks, a depository capable of holding approximately 7500 meters of shelves was established. A small staff was set up and the transferral of archives started from the old archival building.

In order to monitor the climate (humidity and temperature) in the depository, simple cheap commercially accessible instruments were deployed. These were read once a week and the measurements recorded.

The "depository" that the regional States archive of Trondheim moved into in 1993 was fitted with an old ventilation unit that transported a steady stream of unconditioned air into it. This created a number of problems, not at least all the dirt and dust following the air in. But even worse, the depository was filled with humid air, especially on rainy days. As long as the depository was not filed up with a sufficient amount of paper that could act as a buffer stabilising the humidity by absorbing the humidity on rainy days and giving it up on dry days, the climate proved difficult to stabilise. There was no money available for a new automatically adjustable ventilation unit as long as the depository was reckoned to be a temporary solution lasting no more than 10 to 15 years. The dilemma was that the ventilation unit was seen as the key to keep the depository fresh and workable for the staff. After a while a radical solution was reached. As an experiment the ventilation unit was shut down for a week in order to see what happened. What followed surprised everyone. More or less immediately the depository stabilised without the air going stale. Upon working in the depository the air felt as fresh as ever. As a result another test week was agreed on. After that the ventilation unit was never switched back on. The most likely explanation why the ventilation unit was an unnecessary gadget is that there is a weak natural flow of air through the building combined with sheer size of the depository. Being 500 square metres, $6,0 \mathrm{~m}$ high, it held 3000 cubic metres of air. A couple of archivist working no more than some hours a day in the depository never come close to consume a fraction of this amount.

As the clean-up went on in the old archival building, hidden and forgotten archives came back to light in a number nobody had anticipated and filled the temporary depository at Dora more rapidly than expected. After less than two years the regional archive of Trondheim were given the opportunity to let yet another 500 square metres in order to develop a large two story depository comfortably able to hold 15000 shelf meters of documents. This meant that the 
temporary depositary now became larger than the one in the original archive building in the city. The staff grew in order to handle the new amounts of archival material that poured into the depository. It became more and more evident that the institution was in the act of being divided in two separate sections.

\section{From idea to reality}

By the mid-1990s, the owners of Dora I started to realise that the climate in the old submarine pen represented a serious commercial asset. To be given the opportunity to convert parts of Dora I from simple open low-rent warehouse and workshop premises into high cost quality cultural heritage depositories slowly emerged as a profitable business idea. In order to pursue this idea, Dora Ltd in understanding with the Regional State Archive of Trondheim in 1995 started to developed plans for relocating the institution at Dora I. A new archival building was to be constructed in addition to the submarine shelter with the depositories localized inside in the old pens. The plans were presented for the National Archivist during the spring of 1997. In retrospect this was most likely too early for this kind of private entrepreneurship. In 1997, in accordance with tradition, leaders of public funded cultural heritage institutions in Norway still strongly preferred Statsbygg, the Government's construction, property, development and management company to be the landlord establishing and running new facilities for such institutions. Another seven years and a lot of creative and vital political footwork was required before the Ministry of Culture was ready to sign a contract with Dora Ltd commissioning a new archive building in 2003. At this time the vision for the project was significantly expanded: Dora Ltd, in accordance with the political signals in what has come to be known as the "Museum, Library and Archive white Paper", advocated the formation of a regional archival centre. The idea was to co-locate the Regional States archive, The Municipal archives of Trondheim, The University library's archival collection and the Regional inter-municipal archive of Trøndelag, an organisation owned by some 35 municipalities in central Norway. These institutions all had had similar goals and tasks. Localized together, sharing a common reception, reading room, auditoriums, depositories and last but not least a common canteen where the staff from the different institutions could mingle, they were given the opportunity to develop into a strong and flexible professional unit. The Archival centre Dora was opened by Minister Trond Giske in the autumn of 2006.

\section{Climate - measurements and quality}

One strong argument for co-locating all the regional archive institutions in a building next to Dora I was that this represented a unique opportunity to use the climate-stable old submarine pen as quality depositors for the involved institutions. Between 1992 and 2006, sporadic and unsystematic measurement series of temperature and humidity had been collected from 8 different premises 
in Dora I. These measurements were undertaken under the auspices of different personnel in different institutions and with different measuring instruments, some calibrated some not. Most of the measurements series established were short, usually no more than a week or two. All in all this material represents measurement data from 89 months, which is more than 300 weeks or 19000 hours, winter as well as summer. In order to verify the climate in Dora I more closely, a project under supervision by Dr. Svein Carstens on behalf of Dora Ltd was set up. Dr. Jan Holmberg, a well reputed Swedish expert in climate control and preventive conservation for the cultural heritage sector, was asked to evaluate the existing data. In his first and preliminary report, Holmberg concluded that the available data was essentially riddled with methodological flaws. Despite this, there could in his mind be no doubt that Dora I was a very humid and temperature stable building, very well suited for long time storage of paper and other types of organic cultural heritage artefacts.

A scientific follow-up survey, including long-time measurements of temperature and relative humidity, $\mathrm{RH}$, as well as of the air change rate, $\mathrm{ACH}$, and air pollution and emission rate measurements, VOC, was then commissioned by Holmberg. The temperature and RH measurements were conducted by using calibrated instruments from the manufacturer Orion named Tinytag Ultra type TGU-1500 in parallel measurements. Measurement accuracy is specified to \pm $3 R F$. The measurements were conducted in a period stretching from 2006-04-07 to 2006-12-07. The measurements shows that the temperature in Dora I changes slovenly over the year rising some 8 to $10^{\circ} \mathrm{C}$ during the spring summer and autumn before returning back to baseline. On the first floor, the RH is very stable only varying $40-60 \%$. This along with the rest of the data collected led Holmberg to conclude that the long-time measurements of temperature and relative humidity, $\mathrm{RH}$, as well as of air change rate, $\mathrm{ACH}$, air pollution and emission rate measurements, VOC, give evidence that the old submarine bunker is well suited to meet today's European archive requirements as given in ISO 11799:2003, IDT, Information and documentation-Document storage requirements for archive and library materials (Holmberg and Olander [12]).

Furthermore, Holmberg states in his rapport that the room air temperature in Dora I am as stable over the day and over the month as the temperature in an underground rock-cave. This provides stable RH-values. Air conditioning is not needed, to the benefit of both the archive materials and the costs for the archives. The very heavy concrete structure has the necessary buffering capacity. When comparing thermal capacity one finds that concrete is as good as heavy brick. The old concrete structure has over the year's emitted chemicals. The VOC measurements confirm that the emission rate is low today. This means that the property management can propose to potential tenants that quality cultural heritage depositories in the old bunker can be equipped with limited mechanical climate control systems and still meet the requirements.

Later temperature and RH measurements have been conducted by Dr. Svein Carstens. By using the same type instruments and methods as Holmberg, he has conducted a longitudinal study with the duration of two years from 2009 until 2011. Data was collected every hour from five different locations in the old 
submarine pen, three on the ground floor and two on the first floor. This measurement more than confirms Holmberg's conclusions. It furthermore indicates that that Dora I more or less is divided into three separate climate zones. The first and commercially most valuable are located on the first floor of Dora I. Here temperature and humidity is very stable and only changes slovenly over the year (Holmberg [13]). The next zone is the part of the pen located on the ground floor and resting on land. Here the temperature is stable and slightly higher than in the rest of the building. The third and final zone is made up by the part of the first floor still resting in seawater. Here the humidity is higher than in the rest of the building and the humidity in addition fails to reduce when the temperature rises. This indicates that unconditioned air is accessing this part of the building uncontrolled, making it necessary to dehumidify the air in order to make the area suitable as quality cultural heritage depositories.

Today it is generally considered that the main explanation for the existence of the favourable climate in Dora I can be said to be twofold. Firstly, the building's dimensions plays a vital and active part in stabilising the fluctuations in temperature and humidity. Second, essential parts of the building are still resting in seawater. This means that energy can be transported away from the Dora I construction during the warm part of the year, while energy is being supplied from the seawater in the cold season. Together this represents a delicate balance creating the commercially important stability in the building.

\section{Dora today}

As an extension of the fact that Dora Ltd was able to sign a contract with the Ministry of Culture in order to establish the Dora Archive Centre, a number of other regional cultural heritage institutions began to show interest for the unique climate in Dora I. Many of them needed to establish different types of special depositories in order to store parts of or indeed their entire collections. Within a short span of time, the Music Museum at Ringve decided to established a depository for old and large keyboard instruments in Dora I; the University Science Museum established an archaeological depository; the Regional Defence Museum established a multi-material depository with additional workshops containing all types of artefacts documenting the army's varied activity; the Regional Art Museum, responsible for Norway's third largest art collection, established a depository for visual arts; as did The Nidaros Cathedral Restoration Works when they established a special depository for storage of medieval stone and sculpture. Last but not least, the recently created National Rock Museum, Rockheim, decided to establish a depository containing all kind of artefacts documenting Norwegian rock music and lifestyle. This means that at present one third of all rentable area of Dora I am in use by cultural heritage institutions. The archival institutions alone disposes of some 130000 self meters for long time storage of documents.

In recent years, after 2009 the climate in Dora I as well as the security offered by the difficult to penetrate thick concrete shell making up the building has attracted yet another group of tenants. Organizations and institutions in need of 
safe storage and/or processing large amounts of data have stated to use Dora I to create data parks or farms. Like the cultural heritage institutions, these are longterm tenants that in cooperation with the landlord are prepared to make significant investments in order to develop high quality premises for their activity.

\section{Culture Bunker Dora}

In the autumn of 2006 Dora Ltd was asked if it could host "By-larm", an itinerant music festival that aims at launching new Norwegian talents in different popular genres. In mid-February 2007, all vas set for the spectacular event. Six different stages, a hug back stage area, catering facilities and a number of pubs were rigged in the old submarine pen. During a three days period 90 concerts were preformed, attracting some 25,000 visitors. This event became the start of what today is known as "Cultural Bunker Dora". "Cultural Bunker Dora" is a non-commercial project and a registered trademark functioning as a superstructure over a number of different cultural events and activities hosted in Dora. Since 2007, the old submarine bunker has been used as stage for theatre plays, concerts, a number of art exhibitions, performances, large weddings and parties. The different events have been initiated by a number of different programs, institutions, companies, artists and private persons. Dora Ltd's contribution has largely been limited to making suitable areas available for those who have the need.

Under the auspices of the Culture Bunker Dora project, the old barracks used by the soldiers who manned the anti-aircraft guns on the roof of the bunker have been converted into rehearsal and recording studio for local rock bands. And in an abandoned gas station situated in front of Dora I, a number of young photographers and filmmakers had been given the opportunity to establish their own production studios.

The diverse activities under the auspices of the Culture Bunker together with a deliberate marketing of the history of Dora I has greatly changed the status of the building. Earlier it was often portrayed as ugly and unwanted; nowadays it is more often seen and understood as an interesting and valuable part of the city's cultural heritage. Today Dora I even is mentioned in Trondheim's official tourist guide as an interesting place to visit when staying.

The new status Dora I has achieved by developing as an arena for interaction among different cultural institutions, projects and events is reflected in the fact that the "Culture Bunker Dora" is going to host the exhibition "The royal journey" in 2013. This is the Norwegian government's gift to the King and Queen on the occasion of their 75th anniversary. The exhibition is brought about in cooperation between the National Museum of Art, Architecture and Design and the Royal Court. It will put on display examples from the castle one collection of vehicles from the period 1905 to 1940 . 


\section{Uncertain future}

As the work with this paper is about to be closed, the local newspaper reports that the Port Authority of Trondheim is about to complete their plans for filling the sea water basin outside Dora I with toxic waste.

Dora Ltd is the owner of the building Dora I but not the land it is resting on. That land is on a fixed term lease from the Port Authorities.

Trondheim harbour is marked by a thousand years of business. The seabed sediments are proven to contain varying degrees of metal and organic contamination. This toxic waste mainly derives from the earlier practice of discharging industrial waste and sewage directly into the river and canal surrounding the city centre of Trondheim. As a consequence, the sole landowner in the area, the Port Authorities, have been required by the government to clean up. This type of clean-up can quickly become expensive and it is therefore understandable that the Port authorities are looking for cost effective solutions like converting the basin connecting Dora I to the sea into a landfill. If the plan is put into action it represents a serious threat to the natural climate control of the building. In addition this plan will reduce Dora's cultural heritage value as the filling of the basin will leave the building ashore cut off from its natural elementthe sea. It further disguises the true character of the building, making it difficult to understanding why it was erected and used as part a major naval base.

\section{References}

[1] The title of Reichskommissar was given by Adolf Hitler to a number of Nazi governors, mainly in occupied countries during World War II. www.en.wikipedia.org/wiki/Josef Terboven.

[2] On the 25.July 1940, Nikolaus von Falkenhorst (1885-1968) was appointed Wehrmacht Befehlshaber Norwegen, the highest ranking German military officer in Norway. www.snl.no/.nbl biografi/Nikolaus Von Falkenhorst/ utdypning.

[3] Sivertsen, K., Trondhjem i sjøkrigens tegn, (Chapter 6). Trondheim havn $i$ tusen år, ed. B. Seter, Trondheim havn, Trondheim, pp. 108-127, 1997. During the war nearly all the larger German navy vessels came to be stationed in the Trondheim Fjord for shorter or longer periods of time. In February 1942 Tirpitz, Admiral Scheer, Admiral Hipper, Lutzow and Prinz Eugen all were at anchor here. At the most, on 21 March 1942, there were a total of 30 German naval vessels in the fjord.

[4] Brovold, G., Neu-Drontheim i Hitler's regi: og Øysand under krigen, Snøfugl forlag, Melhus, pp.11-140, 1996.

[5] Sivertsen, K., Trondheim i sjøkrigens tegn, (Chapter 6). Trondheim havn $i$ tusen år, ed. B. Seter, Trondheim havn, Trondheim, pp.108-127, 1997. Kriegsmarinewerft Drontheim was technically subordinate to the Oberwerftstab Norwegen and subordinate to the Admiral der norwegischen Nordküste. 
[6] Sivertsen K., Ubåtbunkrene på Nyhavna. Arbok, Arbeiderbevegelsens historielag, pp. 23-41, 2000. The name Dora is derived by the first initial of the German name for Trondheim - Drontheim. D in the German phonetic alphabet is spelled Dora.

[7] Sivertsen K., Ubåtbunkrene på Nyhavna. Arbok, Arbeiderbevegelsens historielag, pp. 23-41, 2000. Organisation Todt (OT) was a big semimilitary engineering organisation named after the German minister of war, Fritz Todt (1891-1942) employing around 60000 people only in Norway in 1945.

[8] Neitzel, S., Die deutschen Ubootbunker und bunkerwerften, Bernard and Graef Verlag, Koblenz, pp.121-123, 1991.

[9] Sivertsen K., Ubåtbunkrene på Nyhavna. Arbok, Arbeiderbevegelsens historielag, pp. 23-41, 2000. This fact combined with the challenging ground conditions extended construction time of Dora I by at least one year.

[10] Sivertsen K., Ubåtbunkrene på Nyhavna. Arbok, Arbeiderbevegelsens historielag, pp.23-41, 2000.

[11] Lovlien, A., Statsarkivet $i$ Trondheim 1850-2000, Riksarkivarens skriftserie 10, Oslo, pp.9-11, 2000.

[12] Holmberg, J.G., and Olander, L., Air quality in a reused submarine bunker. Proc. Of the $9^{\text {th }}$ Int. Conf. on Industrial ventilation. Zurich 2009.

[13] Holmberg, J.G., Evaluering av bevarandeklimatet $i$ arkiv ock magasin, Jan G. Holmberg, Eur. Ing. C. Eng, Teknologie Licentiat, Kungliga Tekniska Hogskolan, Avdeling for Byggvetenskap, Stockholm, pp.1-15, 2006. 